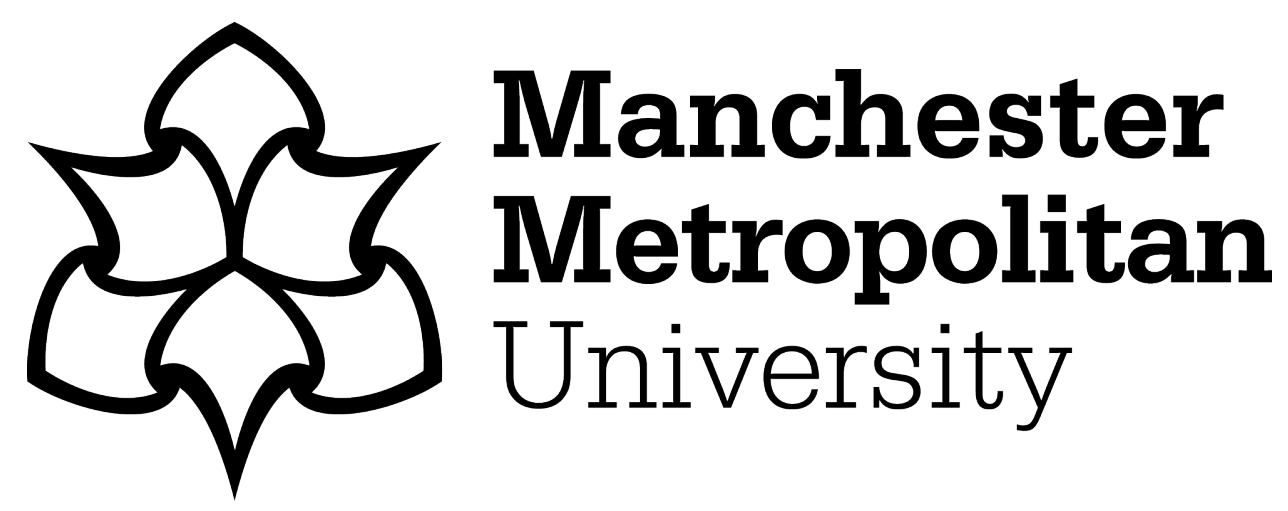

Cardoso, D ORCID logoORCID: https://orcid.org/0000-0001-7864-7531 (2019) The Political Is Personal: The Importance of Affective Narratives in the Rise of Poly-activism. Sociological Research Online, 24 (4). pp. 691708.

Downloaded from: https://e-space.mmu.ac.uk/624057/

Version: Accepted Version

Publisher: Sage

DOI: https://doi.org/10.1177/1360780419835559

Please cite the published version 


\title{
The political is personal
}

\section{The importance of affective narratives in the rise of poly- activism}

\author{
Daniel Cardoso - ECATI-ULHT / NOVA FCSH
}

\begin{abstract}
There is a considerable gap on how social movements that center around non/monogamies decide to organize and articulate their strategies, as well as how they manage their tensions with other activist groups and ideologies (Cardoso, 2014) or even the State (Pérez Navarro, 2017; Vasallo, 2015). In addition to this, the fact that much of the literature that circulates is written in English and in an Anglophone context, hampers the ability of researchers to come into contact with other experiences of non/monogamies. This paper gives a situated account of the rise of the Portuguese polyamorous social movement and shows how interpersonal relationships fundamentally shape the way activism is performed, and how archives are also important in establishing the identity of activists and activist groups (Ahmed, 2014). Using data from the Portuguese polyamorous group PolyPortugal, and interviews to high-profile activists, I argue that the idea of a politics of relating (the politicized analysis of how we connect and perform a given ethics of connection) is a conceptually useful tool to think about the transformations of contemporary intimacies, but it is also fundamental to think about how activism is done by people and for people - people who relate to one another, who exist in tension.
\end{abstract}

Keywords: polyamory, emotion, social movements, political action, non-monogamies, Portugal

\section{Introduction}

This paper will invert the famous feminist adage "The personal is political", by demonstrating how the political is personal - that is to say, how the shaping of political movements also passes through the emotional/affective and personal experiences of specific people, in conjunction with whatever political and ideological strategies might be deployed by them or by the surrounding political scene. The paper also empirically shows how archival is fundamental to this mapping of the flows of emotions and persons, and how it constitutes, rather than just describes or documents, social movements' identities (Ahmed, 2014; Halberstam, 2005). It looks at PolyPortugal, the only Portuguese activist group centered on consensual non/monogamies to date, its coming into being and its transformations during its first five years.

Polyamory is defined (Haritaworn et al., 2006: 518) as "the assumption that is possible, valid and (2006: 518) define it as «the assumption that is possible, valid and worthwhile to maintain intimate, sexual, and/or loving relationships with more than one person" with 
the consent of all involved. Much of the existing research (Moors, 2016) seeks to understand the characteristics and development of polyamorous relationships or of poly identities from an either psychological, sociological or literary studies (Barker and Langdridge, 2010; Schippers, 2016) point of view. Work into discrimination on the other hand has largely looked primarily at issues pertaining to Law (Aviram, 2008; Aviram and Leachman, 2015; Santiago, 2015; Tweedy, 2011), with a special focus on how polyamory might impact on one of the main goals of the global LGBTQ movement - (monogamous) marriage equality $^{1}$ (Ashbee, 2007; Aviram, 2005, 2008; Emens, 2004; Myers, 2009) and how to separate any potential rights for polyamorous persons from conventional religious polygamy (Rambukkana, 2015a, 2015b; Vasallo, 2015).

What is missing in the literature is research that explains the emergence and growth of significance of polyamory as a cultural and political identity since the early nineties (Cardoso, 2011b). Research has looked at community formation - either online (Ritchie and Barker, 2006) or as face-to-face networks (Sheff, 2014), but there has been little work focused on polyamory as a social movement engaged in articulating a political agenda, even though polyamory-related social movements have been growing in activity and prominence.

Given how connected the appearance and mainstreaming of polyamory is to the internet, a further issue that arises is how to define what counts as political participation. Still, I take as baseline the following premises: a) the internet is a space of civic engagement; b) civic engagement is a form of political participation that often lacks a formal or institutional side to it; c) that, nonetheless, civic engagement is fundamental to the plural functioning of democratic societies is not ontologically inferior to formal modes of participation; d) that some modes of political engagement can appear as invisible or even not be perceived as such by those engaging in them; e) that what constitutes the 'political' is contentious and in flux (e.g.: Álvares et al., 2011; Bakardjieva, 2009; Carpentier, 2015; Dahlgren, 2005; Mouffe, 2005; Silveirinha, 2005). This last idea - that the definition of political is in constant flux - is particularly important if we consider how intimate citizenship (Plummer, 1995) means that new areas of life are being opened up to be encompassed by politics. This, in turn, allows for protective intervention of the State in areas like domestic violence, but it also opens up other areas, like same-sex marriage, to State management and thus to homonormativity (Fischel, 2016; Oliveira, 2013; Santos, 2013). This reading - of the tension between formal recognition and coercive normalization - can also be then adapted into issues around non/monogamies (Klesse, 2016a, 2016b). For Ken Plummer, the narrative was the framing strategy that allowed the appearance of intimate citizenship.

\section{Affect/emotions, archives and social movements}

The 'movement' in 'social movements' can be seen in two different ways - the political choices, maneuvers, and allocations of resources in specific geographical spaces (the street, the parliament, the court), but also the flux of ideas and emotions that are behind what those social movements do. Inasmuch as social movements can also be seen as

\footnotetext{
${ }^{1}$ I utilize the phrasing "(monogamous) marriage" to employ "the marked form of an unmarked concept", a concept developed by (Chandler, 2013).
} 
people acting together in a specific way, and people tend to have very strong emotional connections to the activist work they do, contemporary research has taken an affective turn to try to encompass the way emotions work in politics, including in activism and social movements (Demertzis, 2013; Goodwin et al., 2001; Gould, 2004; Hoggett and Thompson, 2012; Nussbaum, 2013; Petray, 2012). Hoggett and Thompson (2012: 3), for instance, do distinguish between "affect and emotion" (unlike other authors below), while simultaneously placing the crux of this affective turn in the taking into account "of our feeling lives which is impulsive, indeterminate and unformed [...] for analyses of the role of human passions in political life".

A main theoretical reference that I wish to highlight here is Sara Ahmed's work on emotions as cultural artifacts that are not simply explained by an idea of interiority, but rather that help shape that interiority:

In my model of sociality of emotions, I suggest that emotions create the very effect of the surfaces and boundaries that allow us to distinguish an inside and an outside in the first place. So emotions are not simply something 'I' or 'we' have. Rather, it is through emotions, or how we respond to objects and others, that surfaces or boundaries are made: the 'I' and the 'we' are shaped by, and even take the shape of, contact with others. (Ahmed, 2014: 10)

This places emotion in a different relation to some of the empirical work done on politics and emotionality - it is not the mere understanding of how internal facts ('emotions') create external facts ('political actions'), but rather the fact that emotions are a means by which the political can take shape, the shape of boundaries that are felt by certain subjects and bodies in certain ways. At the same time, Ahmed is also quick to note the etymological origin of "emotion", and its importance to working with emotions:

Emotions are after all moving, even if they do not simply move between us. We should note that the word 'emotion' comes from the Latin, emovere, referring to 'to move, to move out'. Of course, emotions are not only about movement, they are also about attachments or about what connects us to this or that (Ahmed, 2014: 11)

Studying social movements is, to reiterate, to study movement - and to study movement is, as per the above, to study emotions and how emotions relate to (not) moving: to moving people and ideas and, ultimately, as the title suggests, to invert the known feminist adage "The personal is political" with a version that swaps the components" order. "The political is personal" means that understanding political actions requires us to understand the emotions, the personhoods, that are entwined with it, especially around intimate citizenship, and that no clear split between 'the individual' and 'the group' can be meaningfully articulated without losing much of the nuance that feeds and drives the microsociology of grass-roots activism, of informal organizations, spontaneous protests, and subactivism (Bakardjieva, 2009).

Still following Sara Ahmed, in this paper no attempt is made to distinguish between affects and emotions, and terms are used interchangeably or symbolically connected by a slash. When being interviewed on this matter, she remarked she does "not think it is very helpful" to distinguish between the two (Schmitz and Ahmed, 2014: 98). She also added: "I actually use affect as part of what emotions do. And I am quite critical, in fact, of some 
of the ways in which affect and emotion have been defined as very distinct and clear" (Schmitz and Ahmed, 2014: 97); one such example would be Steve Pile (2010: 8), who sees emotions as being in the realm of the cognitive and the reflexive, and affects as "non- or pre-cognitive, -reflexive, -conscious and -human". I follow here the line of reasoning that if emotions have to do with movement, attachment or connection, these things can also be rightfully considered as experiences of how bodies and objects affect and are affected - thus, affects.

Likewise, Zizi Papacharissi (2015) cogently demonstrates how the split between reason and emotion has no basis on which to stand, especially when considering political engagement. Furthermore, and of particular relevance to the work here, "affect may be a useful component in interpreting forces that drive co-occurrences moving in patterns defined by network complexity", thus making it a factor among many, rather than a sole defining nexus, in the processes of "emerging political formations that take shape through contagion and virality" (Papacharissi, 2015: 17). This author also does not clearly differentiate between affects and emotions, talking about emotions as "fleeting" and affects as "overpowering, albeit occasionally ephemeral", as "groupings [...] of a continuum" (Papacharissi, 2015: 3).

To summarize, then, emotions/affects operate at both the personal and the cultural levels. They are also frameworks that help to understand both the struggles around the shape of 'political', and specific actions undertaken by specific people in a given time and place, in the midst of other relevant factors. There is no social movement without emotion, because to move is to emote, and there are no political actions without political actors who are emotionally embedded in their contexts. While research often looks at how emotions are deployed as strategies, or help understand how movements manifest, rhetorically organize, as noted on the first paragraph of this section, the objective of this paper puts personal affects and emotions at the upstream of the process, not the downstream of it, nor in the flow of it. In looking at how social movements are often the result of collaborative work of many different social actors, the role and relevance of certain key figures - understood here not as a praxeological role or relevance, but as an aggregating affective nexus that often helps structure or drive change, without it being change in itself. So, to understand how PolyPortugal came into being as it did, the emotional experiences of particular people needs to be taken into account, rendering the group as (also) an expression of the emotions of those people, rather than an abstract political entity with a life independent of those connected to it.

Often, the way affects and the role of specific people become consolidated is by archives. The use of archival material is fundamental in two ways: on the one hand, it serves as a record and mark of what happened, connecting past and present; on the other hand, it operates, as J. Halberstam (2005) notes, as a way to create identity and to allow those involved and those who study the archives to engage in continuous processes of meaningmaking. Rethinking how we perceive the past, considering how we might rhetorically project our political actions into the future, contesting the modes of our own subjectivities - all of these things can operate by engaging with archives (Alexander and Rhodes, 2015).

Sara Ahmed (2014: 14) also notes that archives are constituted as "an effect of multiple forms of contact, including institutional forms of contact [...], as well as everyday forms of contact". These multiple forms of contact are often fragmentary, and Halberstam 
reminds us that "the jigsaw puzzle of queer history in the making" (Halberstam, 2005: 170 ) is not simply an amalgamation of objective facts, texts and other cultural products, but rather a becoming of narratives and identities.

I use here references that pertain to "queer archives", not because there is something inherently queer about polyamory - this assumption has had its critique very well made elsewhere (Wilkinson, 2010) - but because there is a parallel between the way discrimination might make some polyamorous folks remain in the closet or be considered as (sexual) dissidents or engage in activism (Petrella, 2007), and the way this happens with Othered sexualities and genders. Gayle Rubin (2007) noted how monogamy was part of how the line between 'good' and 'bad' sexuality is policed.

In this respect, then, I treat the archives of PolyPortugal as an expression of the potentialities of queer archives, and will also show how there is no clean separation- not in Portugal, at least - between a strictu sensu queer archive and what the polyamory activists have done in Portugal. This archival material, alongside with the other methodological elements (see below) will demonstrate the point made above - that specific people's emotions are fundamental to understanding the overarching realities of entire activist groups and social movements.

\section{Polyamory in different cultural settings}

Even though critiques of monogamy from an economic, gendered and political perspective are not new (Engels, 1986; Klesse, 2013; Rosa, 1994), non/monogamies are attacked by being frequently framed as a slippery slope to be used against LGBTQ rights (Myers, 2009; Sheff, 2011) or, not unironically, to defend those same rights (Cardoso, 2014) - and so, more of a danger to 'politics' than a political aspect of intimate citizenship, which clearly exposes the limitations of an inclusion-only legalistic approach to intimate citizenship (Fischel, 2016; Matsick and Conley, 2015; Pérez Navarro, 2017). Polyamory activists do not, however, only get spoken about - they also mobilize in different ways. Hadar Aviram and other colleagues (mentioned above) have, for some years now, been following the way USA polyamorists consider their own identities as a basis for political action. Nathan Rambukkana (2015a) has written on how some of the polyamorist community in Canada has rallied to fight a potentially damaging case brought before the Supreme Court that would have led to the criminalization of polyamorous relationships. Leandro Colling (2015) has written about the tensions of the polyamorous movement vis-à-vis the LGBT movement in Portugal in passing, but mainly in a political and strategic frame of reference.

In Spain, Brigitte Vasallo (2018) is one of the most vocal voices that intersects a critique of monogamy with a critique of islamophobia; here, the coming together of several poly activists has given rise to the appearance of nonmonogamous blocks - SNOFT, for example - in Pride marches in Barcelona (Bernal, 2015). Laura Cordero (2017), from Argentina, gives a historical overview of how anarchism and non/monogamies are deeply entwined and have been experimented with multiple times, by taking into consideration how non-western(ized) modes of relating pre-existed the contemporary concerns around polyamory.

Mônica Barbosa (2015) and Toni Pilão (2015) have written about the activism around non/monogamies in Brazil, noting the characteristics and evolution of activism and the 
field of non/monogamies in general. They particularly note how ideas from the Global North change as they are reappropriated and transformed when recentered around nonWhiteness. Brazil is perhaps one of the most accomplished countries in this aspect, so far, given the steps taken to notarize non-monogamous relationships (G1 Bauru e Marília, 2012; Monteiro, 2015) that has happened several times over, or the recent publication of a book (Rodrigues et al., 2017) in Portuguese aimed at introducing newcomers to a more anarchist variant of non/monogamies, the RLi group (translated, Free Relationships Network). In Brazil, there were attempts at taking advantage of a loophole about domestic partnerships - the number of people that can be part of one is never explicitly stated out in the law. This activist effort exists alongside a great deal of research and academic work done in the area of Law (Sá and Viecili, 2014; Santiago, 2015; Silva, 2014). This work, however, does not include this emotional and affective dimension as a core component of the analysis, and so serves to demonstrate that research on NMCfocused activism is only starting.

The above is, by no means, meant as a full list of all the activities that have been developed as a way to raise awareness for polyamory - in the UK there has been an uninterrupted celebration of a "PolyDay" since 2006, and there is an online "Polyamory Leadership Network" that is mostly US-centric since 2008, for example. Nonetheless, it is my intention to show that activism around polyamory does not function uniformly even when it exists. Furthermore, I contend that a lot of non-Anglocentric modes of political organization are mostly invisible to scholars doing research around non/monogamies, and that there is no overarching, international, situated and comparative perspective on how non/monogamous activism manifests itself at a globalized level.

What is relevant here is that most of the accounts listed above focus mainly on the decisions and strategies undertaken by different activist groups, rather than on the conditions of their emergence, or let alone looking at the internal politics and affectivities of the persons involved in that activism.

As a result, more work is needed - not to establish a definitive history of social movements pertaining to polyamory, but to trace the ways that social movements organize and to inscribe the memory of those movements into how definitions of polyamory and other non/monogamies are constantly contested and negotiated. Moreover, this work should account for the uneven participation of different persons, and consider how personal narratives can deeply impact entire social movements.

\section{Methodology, ethics and researcher positionality}

Before exploring in more depth the methodology deployed or the ethical problems it created, I need to situate (Haraway, 1988) myself. I not only do research on consensual non/monogamies in Portugal, but am also a known spokesperson for the movement, both in activist-led settings and in media framings, having been particularly active at it between 2009 and 2015. This means that I was involved as an activist during a part of the time-frame discussed here, and that my access to other participants and materials was greatly facilitated by the fact that I had only to resort to my own email archive and to my personal experiencing of several of these events, be it in person or in digital spaces. Interviews were conducted with three of those involved in the early stages of the polyamory activist movement in Portugal (out of a set of, arguably, five to six people), all 
of them women over 35 years of age (one as a face-to-face interview, and two over videoconference, as they were not in Portugal at the time). Consent was obtained before the interview was conducted, and the interviews took from half an hour to a little over an hour. The interviews were not fully transcribed, but closely listened to, with annotations made to some passages marking the most significant aspects of the interviews. Because the purpose was not to identify themes or to quantitatively process the interview, the interviews' main parts - regarding both events that happened, and the affective aspect of those - were identified and organized to then develop the critical chronology presented below.

The emails were present in my own archive or accessible through my own account as part of that mailing list but, to simplify the analysis and focus on the main objective, only the first 6 years (2004-2009) were searched for emails of the individuals who participated directly in this project via the interviews, or emails that signaled specific events. To ensure the privacy of others, no other information was collected or analyzed. This timespan saw the exchange of over 7 thousand emails but, as mentioned, these were not exhaustively processed.

The account that follows is, in most part, chronological, because it helps trace out the personal movements that are central to the appearance of a polyamory activist scene in Portugal, and seeks to divide the first five years of the emergence of poly-activism in Portugal in three great moments, connected to wider sociohistorical events and contexts, but particularly to how some people felt moved to action, or moved away from that same action, into other geographies. These three main moments are: the 'zero moment', the consolidation phase, and the outwards openness phase.

\section{Polyamory in Portugal - several beginnings}

PolyPortugal was created in September 26, 2004, as a mailing list on Yahoo! Groups by $V^{2}$ - and was not yet called PolyPortugal. At the time, Portugal was undergoing a period of economic growth (considering GDP per capita) and yet a period of relative disinvestment in Education, and a right-wing government was in power since 2002, although with some political turbulence (the then-Prime Minister, Durão Barroso, resigned, was replaced by another member of his party, and then Social-Democrats lost the next general election). At the same time, as Cascais (2006: 123) points out, this was a period where activism around sexualities and gender erupted into the Portuguese public sphere and public spaces, as many new groups were founded from 2000 onwards, and some became "privileged interlocutors before political parties and government bodies when it came to present legislative proposals".

The dynamics of activism are often fluid, uncertain, unamenable to being pinned down into specific dates or formats, and so what I try to trace here is a circulation of affects and effects that have people, efforts, and meeting points in common. This creates $a$ narrative about polyamory in Portugal, not the narrative. Because of this, "PolyPortugal" as an entity is less of a certainty, and more of an agglomeration of relationships and strategies that developed and have been developing in different physical and digital spaces at once.

\footnotetext{
${ }^{2}$ For privacy reasons, real names have mostly been changed or omitted in line with how participants wanted to be identified; to obfuscate which are which, they all appear similarly marked.
} 
The organizing core of how that name was born is this mailing list, and all subsequent dynamics evolved from people who met there or who used it to organize and connect; any reference to "group", "mailing list", or "initiative" pertains to this loosely connected thread of meaning. This has had an obvious impact in what was done, by whom, through which decision processes, even though that was not apparent later on - this can help us understand how feelings of belonging (or not) can help shape (in)activity.

But even though this was the first mailing list, it was not the first moment of activism around polyamory in Portugal. Less than a month after the mailing list's foundation, the founder spoke, in an email sent to the mailing list, of another website, created by Lara, which was probably the first one in Portugal dedicated to polyamory, specifically. As Lara recalled in her interview, the absence of material around non-monogamies drove her to create the website - an emotion, here, generated in comparison to her experiences in other countries made all the more stark by the fact that polyamory as a noun had appeared over a decade earlier (Cardoso, 2011a). More than aspiring to occupy the place of 'activist', it was a dearth of resources aimed at Portuguese-speaking people (especially the ones in Portugal, rather than in Brazil) that was behind Lara's action to create a repository of information and a contact point for other people who might feel similarly, rather than for people with the same political or social views.

The affective absence that was felt, and the lack of circulation that it brought along, was a driving force behind several of these actions, showing that emotions, good and bad, and the affective narratives constructed around them, are fundamental to understand the paths activism takes.

It wasn't until December $14^{\text {th }}, 2005$, that another important person made her presence known - Mónica joined the mailing list and shared her resolve to become more "active and activist", following a newspaper article on Guardian and the 2005 International Polyamory Conference in Hamburg (En-Griffiths et al., 2018), as well as her connection to what was happening in Germany in terms of polyamory activism. She also shared her own blog, where more information about polyamory could be found. In addition to Lara's website, then, this blog became another aggregating nexus of polyamory in Portugal, although one that framed it in a more explicitly political way, as can be seen by the use of "activist" by Mónica. Her testimony also demonstrates how media presence and visibility can act as a call to action within a pre-existing context of political orientation towards activity - likewise in regards to academic activity and legitimation of researching topics around intimate citizenship.

\section{Activation and consolidation of affective networks}

This marks the transition between a 'zero moment' in organized polyamory activism, to a phase of consolidation. About as many emails where exchanged during the first year of the mailing list as during the two weeks after Mónica joined it, which emphatically demonstrates the difference that one person and their affectively charged actions can make, as well as serving as a poignant demonstration of the power of archives to understand and become a group's existence. Examples such as this reinforce the main argument laid out here: that the dispositions, affects, sentiments and energy of specific people can operate in a way that is just as meaningful as the context they are in, or the material resources they have available. 
Before this moment, there was Lara's website and a few initiatives from her to hold informal meetings in Lisbon, again showing how polyamory not only constituted a mode of intimate citizenship in Plummer's sense, but also as an emergent identity that had interpersonal connection as its main motif. The 'first moment', framed as it was by the aforementioned increase in overall activism in Portugal, still needs to be considered from a more personal and affective perspective.

This commitment by Mónica to be "active and activist" is worthy of a second look. When I asked her about the context where she was coming from, and its importance, she said that she was "still very fascinated with the lesbian and trans scene, with a lot of connections to self-organized, non-hierarchical, biological farms, with leaderless, horizontal, DIY activism"; " and I found that to be very powerful!", she added. As I read it, Mónica's political and activist experiences were moving and influential, they helped to constitute, for her, a sense of affinity with the German activists, one which she tried to extend to Portugal. Her political experiences had a profound personal impact, and this energized her, moved her.

Those experiences were being moved to different spaces and people through her, and it was the not the characteristics of the German activist praxis in itself that explained how Mónica acted, but the emotions that such praxis gave way to. Zizi Papacharissi (2015: 71) talks about "connective action", a mode of political engagement that "organically takes form as self-motivated actors share personally expressive messages across networks and as interconnected actors view, rebroadcast, and further remix them". Even though the author refers here to messages that are spread on Twitter, my argument here is that "messages" can also refer to Mónica's perception and testimony of how German activists organized themselves and acted politically.

This creates an affective network - a complex mesh of emotions and circulations through and in bodies, that connects different spaces, different people, and which has a multitude of effects and expressions that cannot be reduced to intentional action, but that also does not fully exist outside intentionality, as emotions are put into conscious action. This emotionality that Mónica attested to turned into motion, and we can see here how these experiences move with the subjects when they also move, physically, to other spaces. Even positive experiences can be interwoven with negative aspects, presenting as feelings of estrangement, and negative feelings don't necessarily need to encompass a turning into inaction. Mónica comments how "all the notions about non-violent communication and communication rules, and about conflict de-escalation, for my own shame, weren't learned here [in Portugal]".

As she both identifies with being Portuguese, but disidentifies with some aspects of what she did not learn here and the cultural constraints around such learnings, there is tension, and different belongings are simultaneously mobilized. This tension can also be understood as a wish - a desire that things were different here, that someday someone can learn these skills here, which in turn links back to how she presents as being mobilized. As Mónica moved to Porto, a city in Portugal, she started to help organize informal meetings there too, along with a person from another group, Paula Valença. Again, here, the interpersonal aspect is important in different ways. Mónica heard about a group, Bi Portugal, via her personal and political connections to yet another group, the Panteras Rosa (translated: Pink Panthers). 
When interviewed, Paula retold how she was connected to activism in the UK, especially in the area of bisexuality. It was also in that milieu that she had "community and activist connections with polyamorous persons", which meant she was "familiar with the poly community in London", since it overlapped significantly with the bisexual community. The use of this specific word - familiar - with all the implications of emotionality and human connection gave Paula not only information about something that, in Portugal at the time, was barely known, but also an affinity that then facilitated the connection with Mónica.

What this means is that different contexts - the UK and Germany - each with their specific activist cultures, generated similar emotional responses and opened desires that resonated and helped them come together, turning those perceived lacunae into plans and action.

That does not mean that this was easy or simple: Mónica reported how in the first meetings "there were a lot of people near our table, pretending to have nothing to do with us, but at the same time trying to see what was going on [...] it was quite a farcical situation, it's one of those things that annoys [me] about 'closets' and about a certain cowardice that you can find here in Portugal".

The cultural dimension of emotions that Sara Ahmed (2014) mentions has this effect as counterpoint - a culturally shared experience of shame and fear can also present itself as ambiguity and drive behavior in two opposing directions - being present and not-being present, those who came to the meetings struggled with what was, I would argue, the internalized perception of uncertainty, and also an attempt to deploy curiosity to "up futures, in the ways [emotions] involve different orientations to others" (Ahmed, 2014: 202). Paula's and Mónica's commitment to organize those meetings clashed with other people's fear of what might happened in those meetings, which in turn clashed with Mónica's expectations, desires and identifications - but all of these involve emotions as present outlooks into future expectations.

The being there, the not-engaging in conversation, the curiosity and the exasperation - all of those things are viewable as political, but they also represent deeply emotional experiences for those involved, full of ambivalence and even a degree of lack of empathy. To understand all of these decisions requires some knowledge of what it's like to be - in this case - a bisexual or a polyamorous person in Porto in the noughties, but also an understanding of how feelings can both mobilize people to come and make them not approach the organizers. Negative and positive emotions can come together to organize action and inaction simultaneously.

Another deeply emotional event - one that would go on to leave a mark upon the entire history of Human Rights' activism in Portugal - happened in Porto: Gisberta, a transsexual, HIV+, migrant, paperless, sexworker, woman, was brutally murdered by a group of youngsters in 2006. This spurred several groups to create the first Pride March outside of Lisbon. Paula Valença characterizes this as a "very organic response" to Gisberta's murder, and that it was more than an LGBT march, as the issues at hand intersected not only trans rights, but also sex work, racism, classism and sexual violence, among others, unlike what happened in Lisbon. The use of anger is far from new, when it comes to helping mobilize and make visible discrimination (Gould, 2009).

And so it became that PolyPortugal, via Mónica, became one of the founding groups of the Porto LGBT Pride parade. But a closer look at the emotional nuances at stake clarify 
how this happened: according to Mónica, Paula Valença challenged her to attend an Organizational meeting, but Mónica was "entertained with my PolyPortugal, trying to find people to join, and also trying to manage my own poly-chaos". So, it can be interpreted that, for Mónica, this first initiative felt counter-intuitive, her affective energies already being positively deployed in other ways, and having to deal with "polychaos". Mónica traces her linkage to emotions and potential inaction in two ways - her personal life (the "poly-chaos") and her appropriation of the group as a project that felt "hers", even though she was not its creator. Here, again, we see how personal elements, deeply felt, did shape the history of PolyPortugal - on the one hand, Mónica's attachment to the project almost drove her from actually politicizing it more explicitly; on the other hand, her affective experiences with other people (Goodwin et al., 2001) seem to be presented here as another obstacle and an affective drain or nexus that would prevent her from having enough capacity to do so.

\section{Acting outwards - PolyPortugal as a visible collective}

Added to this, there was Mónica's belief that other groups might not acknowledge her or PolyPortugal's legitimacy to be there. Up until here, PolyPortugal existed first and foremost as a support networked turned more inwards than outwards, functioning as a form of resistive space against normative discourses and emotions relating to monogamy. This effort created interpersonal connections that then facilitated a moment of more formal effort-building.

This represented another turning point for PolyPortugal and for polyamory activism in Portugal. Whereas other activities so far had been more about forms of what Maria Bakardjieva (2009: 36) calls "subactivism" ("an individual, day-to-day, small-scale decisions and actions that have a political and / or ethical basis"), the co-founding of the Porto Pride March was a movement outwards, which was premised on the intersectionality of the Porto march, on the importance of going beyond specific 'LGBT issues' and focusing on the lived experiences of minorities and overlapping systems of oppression (Crenshaw, 2008; Schippers, 2016). The suddenness, shock and grief coming from Gisberta's death served to energize and gather support from left-wing groups, who extended their solidarity to the role that PolyPortugal could have in organizing the march. Like in previous research (Gould, 2009), then, negative affects can be an incredibly powerful way to create and enact survival strategies that go beyond the denunciation of systemic problems, to the creation of different and positive ways to build community (Sedgwick, 1997).

In spite of this, and given the geographical nature of political and activist work, it wasn't until 2010 that PolyPortugal co-organized the Pride March in Lisbon as well, which is further discussed elsewhere, including the way such blockages came not only from political differences, but also from the negatively invested emotions of key personalities within the LGBT movement in Portugal (Cardoso, 2014).

However, the group mobilized at least in 2008 and 2009 to distribute pamphlets and to make themselves visible in Lisbon during the March, and create awareness about the topic. The need for this was in no small part related to how, even in Porto, the political alliances were changing - in 2009 there was an attempt to delete any reference to nonmonogamies from the March's Manifesto. As mentioned in the Introduction section, the 
mobilization behind monogamous same-sex marriage legislation created a hostile environment that intended to present a normalized and respectable front that would turn dissidents into worthy citizens, with unconstitutional legislation being overturned the momentary victory.

In the meantime, and throughout all of these years, but more intensely so from 2009 onwards, several people from the group participated in the media - radio shows, newsmagazine articles, and even TV shows. Thus, the second moment of polyamorous activism in Portugal had to do with an opening up - first before the rest of the activist groups that existed or were being created, and secondly before the wider Portuguese public, by engaging with mainstream press and claiming space within the journalistic agenda.

The consolidation of this tendency for outwards exposure was coupled with a diminishing of more internal forms of organization, such as regular face-to-face encounters. The context for this activism was also changing - the economic crisis created and amplified economic precarity, emigration, and reduced the time and energy available for many. This diminished the amount of people willing to engage in activism, made others leave the country - and here Mónica and Paula are two great examples of that, given their importance, expertise and background in activism. Those who remained were mainly connected to participation alongside other activist groups and mainstream media engagement.

The pushback from some more institutionalized areas of the LGBT movement was coincidental with a speeding up of how the term "polyamory" was moving in the press, and from 2009 onwards the journalist contacts aimed at finding someone to talk about polyamory grew, as grew the amount of events aimed at outsiders from the polyamorous community - public speaking events co-organized with other activist groups, more focused blogging (the blog "PolyPortugal" was created in June 2009), the public presentation of the first Portuguese Master's thesis on the topic (Cardoso, 2010), the creation of more pamphlets and more online visibility were the key features of this moment.

The regular meetings became irregular, and usually took the form of picnics in public parks, rather than discussion groups in cafés - more complex events but also rarer, and mostly organized by a small group of people, taxing them in ways that were sometimes evident in how the mailing list was also used to complain about the lack of multiple organizational nodes. The lack of energy or sense of safety associated with public exposure also served to create a situation where only a very small group of people would appear publicly associated with PolyPortugal, and thus receive further invitations to speak for PolyPortugal and about polyamory. So, just as negative emotions can have a mobilizing effect, other negative emotions can create a chilling of the mood that specific people have in relation to social movements, even as their outwards appearance is one of acceleration and success.

Technological shifts in Portugal can also help frame this third phase: Facebook was fundamental in two ways, as it expanded the reach that PolyPortugal could have, both as a "group" (which could be used for emotional and group support as the mailing list had been) and as a "Page" (which focused more on public visibility), but it also drew people away from the mailing list, and turned into the central hub of conversation and sociality. 
This introduced deep changes into the modes and practices of engagement of people around polyamory, as well as their perception of finding and building community, by promoting online conversations and also by enmeshing polyamory activism in the social dynamics of representation and political presence of PolyPortugal and other activist groups.

The archival potentialities of these platforms (Facebook and Yahoo! Groups, where the original mailing list is hosted) were also vastly different, and so were the kinds of engagement that ensued. Mailing lists, operating on a slower time and inviting longer and more thought-out texts that then get replicated into each user's email box, have been giving way to the faster-paced and shorter messaging and quick-fire replying for which Facebook is famous. While the former can more easily create an archive - indeed, a multitude of archives, as emails are replicated, deleted, forwarded, saved offline -, the latter seems invested in forgetfulness, in repetition and in a temporality that delivers all moments as a single moment.

Even though the timeframe for this article's analysis stops before the full implementation of Facebook as the locus of polyamory activism and engagement, these dynamics were apparent from the moment that the shift was made from the mailing list into Facebook and Mónica expressed this on the mailing list at the time; that would later compound into her leaving the group altogether. As Zizi Papacharissi (2015: 71) points out, this might mean a more loosely defined 'we', but can still result in significant social mobilization, as technologies deployed frame and structure how actions are undertaken, but not what actions are and are not undertaken.

\section{Closing remarks and future directions}

The focus of this analysis was on the most relevant features of three periods in the history of the polyamorous movement in Portugal, starting in 2004 and going into mid-2010. After a 'zero moment', in-group organization and association appeared, then public outreach via activism around public events (as Pride Marches) along with media connections, emptying most of the face-to-face dynamics alongside a renewed focus on online communication, public engagement events and media appearances.

These three periods, and their specific dynamics, are here to serve as a baseline for how PolyPortugal has never lost an explicitly political edge, one that was facilitated by these very personal and affective connections, and one that represented deep changes for the lives, and affects, of many afterwards.

Looking at affects and the political as personal does not suffice to clearly understand even this small part of PolyPortugal's history. Nevertheless, I demonstrated above how these elements are inextricable from the path poly-activism took in Portugal, and especially so in pivotal moments. To be able to provide a better account of the historical situatedness of the appearance and functioning of activism around non-monogamies, is to look at the lives of particular activists and their emotional environments, accompanied by how the curation of archives is done (or not done), and how different media platforms impact on the identity-building of groups.

Looking at activism and political action must also be to look at persons who are complex in themselves and operate as more than 'political actors', and whose emotions help shape their political actions, as well as shape the meaning of 'political' and the meaning of 
'personal', in different ways than those implied by "the personal is political". To think how 'personal' and 'political' articulate each other requires a thinking through the ambivalence of both terms, and through the flows of meaning that operate in both directions.

The main contribution this paper brings is a challenge for the analysis of affect and movement in relation to non-monogamies' activism - that it moves away from presenting only the political choices and rhetoric, and into the mapping of specific activists and their personal driving forces, or personal barriers. To put it differently, this is a challenge to bring to the fore the microsocial narrative as being just as important as contextual approaches to political action.

The Portuguese poly-activism cannot be understood in isolation from a wider international context that draws from several different places in Europe, and elsewhere. Therefore, a mapping out of the several activisms around consensual non-monogamies, how they conflict, interact, connect or compete is fundamental to understand both the macro-social dynamics it entails, but also the micro-social dynamic pertaining to specific countries or even cities.

As Paula told me, after being shown a draft of this paper, this is about "the personal that generates the political that extends the personal that becomes political". This circularity shows the bidirectionality of social action, and the enmeshing of micro- and macro-levels of analysis. It shows that a clear understanding of social movements has much to do with cultural and socioeconomic context, but also much to do with how the affective charge that some people carry can help stimulate the movement of many others, and those actions, take together, coalesce into social movements.

\section{Bibliography}

Ahmed S (2014) The Cultural Politics of Emotion. 2. ed. Edinburgh: Edinburgh Univ. Press.

Alexander J and Rhodes J (2015) Sexual Rhetorics: Methods, Identities, Publics. Routledge.

Álvares C, Martins IR and Cardoso D dos S (2011) Argumentação numa esfera pública reticular: as vozes femininas online. Comunicação \& Informação 14(2): 47-65. DOI: $10.5216 /$ cei.v14i2.22444.

Ashbee E (2007) Polyamory, Social Conservatism and the Same-Sex Marriage Debate in the US. Politics 27(2): 101-107. DOI: 10.1111/j.1467-9256.2007.00285.x.

Aviram H (2005) How Do Social Movements Decide to Move? Polyamorous Relationships and Legal Mobilization. SSRN Electronic Journal. DOI: 10.2139/ssrn.728725. 
Aviram H (2008) Make Love, Now Law: Perceptions of the Marriage Equality Struggle Among Polyamorous Activists. Journal of Bisexuality 7(3-4): 261-286. DOI: 10.1080/15299710802171332.

Aviram H and Leachman G (2015) The Future of Polyamorous Marriage: Lessons from the Marriage Equality Struggle. Harvard Journal of Law \& Gender 38: 269-336.

Bakardjieva M (2009) Subactivism: Lifeworld and Politics in the Age of the Internet. The Information Society 25(2): 91-104. DOI: 10.1080/01972240802701627.

Barbosa M (2015) Poliamor e Relações Livres: Do amor à militância contra a monogamia compulsória. Rio de Janeiro: Luminária Academia.

Barker M and Langdridge D (eds) (2010) Understanding Non-Monogamies. Routledge research in gender and society 23 . New York: Routledge.

Bernal M (2015) El amor después del amor. elPeriódico, 16 December. Online. Barcelona. Available at: https://www.elperiodico.com/es/barcelona/20151216/elamor-despues-del-amor-barceloneando-poliamor-amor-plural-4757432 (accessed 14 March 2018).

Cardoso D (2010) Amando vári@s - Individualização, redes, ética e poliamor. Tese de Mestrado em Ciências da Comunicação. Faculdade de Ciências Sociais e Humanas - Universidade Nova de Lisboa, Lisboa.

Cardoso D (2011a) Poliamor, ou Da Dificuldade de Parir um Meme Substantivo. Interact (17). Available at: http://interact.com.pt/17/poliamor/ (accessed 8 March 2011).

Cardoso D (2011b) Polyamory, or The Harshness of Spawning a Substantive Meme. Interact (17). Available at: http://interact.com.pt/17/poliamor/ (accessed 8 March 2011).

Cardoso D (2014) My Spivak is bigger than yours: (Mis-)representations of polyamory in the Portuguese LGBT movement and mononormative rhetorics. LES Online 6(1): 45-64.

Carpentier N (2015) Differentiating between access, interaction and participation. Conjunctions. Transdisciplinary Journal of Cultural Participation 2(2): 7-28. DOI: $10.7146 / \mathrm{tjcp} . \mathrm{v} 2 \mathrm{i} 2.22915$.

Cascais AF (2006) Diferentes como só nós: O associativismo GLBT português em três andamentos. Revista Crítica de Ciências Sociais (76): 109-126.

Chandler D (2013) Personal communication on Facebook. Available at: https://www.facebook.com/danielscardoso/posts/10201839520183891?comment $\mathrm{id}=65934568 \&$ offset $=0 \&$ total_comments $=20$. 
Colling L (2015) Que Os Outros Sejam o Normal: Tensões Entre o Movimento LGBT e o Activismo Queer. Edfuba.

Cordero LF (2017) Amor y Anarquismo: experiencias pioneras que pensaron y ejercieron la libertad sexual. SIGLO XXI EDITORES.

Crenshaw KW (2008) Mapping the margins: Intersectionality, identity politics and violence against Women of Color. In: Bailey A and Cuomo CJ (eds) The Feminist Philosophy Reader. Boston: McGraw-Hill, pp. 279-309.

Dahlgren P (2005) The Internet, Public Spheres, and Political Communication: Dispersion and Deliberation. Political Communication 22(2): 147-162. DOI: 10.1080/10584600590933160.

Demertzis N (ed.) (2013) Emotions in Politics. Palgrave Macmillan. Available at: http://www.palgraveconnect.com/doifinder/10.1057/9781137025661 (accessed 23 March 2016).

Emens EF (2004) Monogamy's Law: Compulsory Monogamy and Polyamorous Existence. New York University Review of Law \& Social Change 29: 277. DOI: $10.2139 / \mathrm{ssrn} .506242$.

Engels F (1986) A Origem Da Família, Da Propriedade Privada e Do Estado. Lisboa: Avante.

En-Griffiths D, Cardoso D, En B, et al. (2018) Editorial: Non-Monogamies and Contemporary Intimacies. En-Griffiths D, Cardoso D, En B, et al. (eds) Graduate Journal of Social Science 14(1): 4-7.

Fischel JJ (2016) A More Promiscuous Politics. LGBT Rights without the LGBT Rights. In: Ball CA (ed.) After Marriage Equality: The Future of LGBT Rights. New York: New York University Press, pp. 181-211. DOI: $10.18574 / \mathrm{nyu} / 9781479883080.001 .0001$.

G1 Bauru e Marília (2012) União estável entre três pessoas é oficializada em cartório de Tupã, SP. Available at: http://g1.globo.com/sp/baurumarilia/noticia/2012/08/uniao-estavel-entre-tres-pessoas-e-oficializada-emcartorio-de-tupasp.html?utm_source=facebook\&utm_medium=social\&utm_campaign=socialread er (accessed 29 November 2015).

Goodwin J, Jasper JM and Polletta F (eds) (2001) Passionate Politics: Emotions and Social Movements. Chicago: University of Chicago Press.

Gould DB (2004) Passionate Political Processes: Bringing Emotions Back into the Study of Social Movements. In: Goodwin J and Jasper JM (eds) Rethinking Social Movements: Structure, Meaning, and Emotion. People, passions, and power. Lanham, Md: Rowman \& Littlefield Publishers, pp. 155-175. 
Gould DB (2009) Moving Politics: Emotion and ACT UP's Fight against AIDS. Chicago: The University of Chicago Press.

Halberstam J (2005) In a Queer Time and Place: Transgender Bodies, Subcultural Lives. Sexual cultures. New York: New York University Press.

Haraway D (1988) Situated Knowledges: The Science Question in Feminism and the Privilege of Partial Perspective. Feminist Studies 14(3): 575-599. DOI: $10.2307 / 3178066$.

Haritaworn J, Lin C and Klesse C (2006) Poly/logue: A Critical Introduction to Polyamory. Sexualities 9(5): 515-529.

Hoggett P and Thompson S (2012) Politics and the Emotions: The Affective Turn in Contemporary Political Studies. New York: Continuum. Available at: http://public.eblib.com/choice/publicfullrecord.aspx?p=894550 (accessed 23 March 2016).

Klesse C (2013) Poly Economics - Capitalism, Class, and Polyamory. International Journal of Politics, Culture, and Society 27(2): 203-220. DOI: 10.1007/s10767013-9157-4.

Klesse C (2016a) Marriage, Law and Polyamory. Rebutting Mononormativity with Sexual Orientation Discourse? Oñati Socio-Legal Series 6(6): 1348-1376.

Klesse C (2016b) The Spectre of Promiscuity: Gay Male and Bisexual Non-Monogamies and Polyamories. Routledge.

Matsick JL and Conley TD (2015) Maybe “I Do,” Maybe I Don’t: Respectability Politics in the Same-Sex Marriage Ruling. Analyses of Social Issues and Public Policy: n/a-n/a. DOI: 10.1111/asap.12085.

Monteiro MA (2015) Relacionamento a três: união de 'trisal' é reconhecida por lei. Tribuna da Bahia, 24 November. Available at: http://www.tribunadabahia.com.br/2015/11/24/relacionamento-tres-uniao-detrisal-reconhecida-por-lei (accessed 29 November 2015).

Moors AC (2016) Has the American Public's Interest in Information Related to Relationships Beyond "The Couple" Increased Over Time? The Journal of Sex Research: 1-8. DOI: 10.1080/00224499.2016.1178208.

Mouffe C (2005) On the Political. Psychology Press.

Myers GA (2009) Drawing the Line: Slippery Slopes, Sex Panics, and Polyamorous Marriages. Available at: http://works.bepress.com/gretchen_myers/1/.

Nussbaum MC (2013) Political Emotions: Why Love Matters for Justice. Cambridge: The Belknap Press of Harvard University Press. 
Oliveira JM de (2013) Sexual citizenship under suspicion: a meditation on the homonormative and neoliberal foundations of a 'consolation' citizenship. Psicologia \& Sociedade 25(1): 68-78. DOI: 10.1590/S010271822013000100009 .

Papacharissi Z (2015) Affective Publics: Sentiment, Technology, and Politics. Oxford studies in digital politics. Oxford ; New York, NY: Oxford University Press.

Pérez Navarro P (2017) Beyond Inclusion: Non-monogamies and the Borders of Citizenship. Sexuality \& Culture 21(2): 441-458. DOI: 10.1007/s12119-0169398-2.

Petray TL (2012) A walk in the park: political emotions and ethnographic vacillation in activist research. Qualitative Research 12(5): 554-564. DOI: $10.1177 / 1468794112446048$.

Petrella S (2007) Ethical Sluts and Closet Polyamorists: Dissident Eroticism, Abject Subjects and the Normative Cycle in Self-Help Books on Free Love. In: Rumens $\mathrm{N}$ and Cervantes-Carson A (eds) Sexual Politics of Desire and Belonging. At the interface 36. Amsterdam: Rodopi, pp. 151-168.

Pilão A (2015) Entre a liberdade e a igualdade: princípios e impasses da ideologia poliamorista. Cadernos Pagu (44): 391-422. DOI: 10.1590/18094449201500440391.

Pile S (2010) Emotions and affect in recent human geography. Transactions of the Institute of British Geographers 35(1): 5-20. DOI: 10.1111/j.14755661.2009.00368.x.

Plummer K (1995) Telling Sexual Stories: Power, Change and Social Worlds. New York: Routledge.

Rambukkana N (2015a) Fraught Intimacies: Non/Monogamy in the Public Sphere. Sexuality studies series. Vancouver; Toronto: UBC Press.

Rambukkana N (2015b) Unmappable Subjects: Intimacy, Privilege and Polygamous Women in Canadian Public Sphere Discourse. Keynote Speech. Faculdade de Ciências Sociais e Humanas. Available at: https://www.youtube.com/watch?v=NZBuhUc0Zi8 (accessed 28 June 2016).

Ritchie A and Barker M-J (2006) 'There Aren't Words for What We Do or How We Feel So We Have To Make Them Up': Constructing Polyamorous Languages in a Culture of Compulsory Monogamy. Sexualities 9(5): 584-601.

Rodrigues M, Campos R, Sieber R, et al. (2017) Relações Livres: Uma Introdução. coleção RLI 1. Porto Alegre: RLI-E. 
Rosa B (1994) Anti-Monogamy: A Radical Challenge to Compulsory Heterosexuality? In: Griffin G, Hester M, Rai S, et al. (eds) Stirring It: Challenges for Feminism. Feminist perspectives on the past and present. London; Bristol, PA: Taylor \& Francis, pp. 107-120.

Rubin G (2007) Thinking Sex: Notes for a radical theory of the politics of sexuality. In: Parker R and Aggleton P (eds) Culture, Society and Sexuality: A Reader. 2nd ed. New York: Routledge.

Sá CF de S and Viecili M (2014) As Novas Famílias: Relações Poliafetivas. Revista Eletrônica de Iniciação Científica 5(1): 137-156.

Santiago R da S (2015) Poliamor e direito das famílias: reconhecimento e consequências jurídicas. Curitiba: Juruá.

Santos AC (2013) Are we there yet? Queer sexual encounters, legal recognition and homonormativity. Journal of Gender Studies 22(1): 54-64. DOI:

10.1080/09589236.2012.745682.

Schippers M (2016) Beyond Monogamy: Polyamory and the Future of Polyqueer Sexualities. New York: NYU Press.

Schmitz S and Ahmed S (2014) Affect/Emotion: Orientation Matters. A Conversation between Sigrid Schmitz and Sara Ahmed. FZG - Freiburger Zeitschrift für Geschlechterstudien 20(2). DOI: 10.3224/fzg.v20i2.17137.

Sedgwick EK (1997) Paranoid Reading and Reparative Reading; or, You're So Paranoid, You Probably Think This Introduction Is About You. In: Novel Gazing: Queer Readings in Fiction. Durham: Duke University Press, pp. 1-37.

Sheff E (2011) Polyamorous Families, Same-Sex Marriage, and the Slippery Slope. Journal of Contemporary Ethnography 40(5): 487-520. DOI: $10.1177 / 0891241611413578$.

Sheff E (2014) The Polyamorists next Door: Inside Multiple-Partner Relationships and Families. Lanham: Rowman \& Littlefield Publishers, Inc.

Silva B de J (2014) Expressões contemporâneas das relações afetivo amorosas: a emergência do Poliamor. GETPol - Anais Colóquio do Grupo de Estudos de Teoria Política 2(1).

Silveirinha MJ (2005) Democracia deliberativa e reconhecimento: repensar o espaço político. In: Correia JC (ed.) Comunicação e Política. Estudos em Comunicação. Covilhã: UBI Labcom, pp. 147-180.

Tweedy AE (2011) Polyamory as a Sexual Orientation. University of Cincinnati Law Review (79): 1461. 
Vasallo B (2015) Dismantling monogamy, far beyond the exclusivity issue. Keynote Speech. Faculdade de Ciências Sociais e Humanas. Available at: https://www.youtube.com/watch?v=NZBuhUc0Zi8 (accessed 28 June 2016).

Vasallo B (2018) Pensamiento monógamo, terror poliamoroso. La Oveja Roja.

Wilkinson E (2010) What's queer about non-monogamy now? In: Barker M and Langdridge D (eds) Understanding Non-Monogamies. Routledge, pp. 243-254. 